\title{
The investigation of the luminescence properties of colloidal quantum dots based on cadmium chalcogenides
}

\author{
I.I.Mikhailov, S.A.Tarasov, A.V.Solomonov, \\ L.B.Matyushkin, D.S.Mazing \\ Saint Petersburg Electrotechnical University "LETI", \\ 5 Prof.Popov Str., 197376 St. Petersburg, Russia
}

Received October 30, 2013

\begin{abstract}
Samples of cadmium selenide colloidal quantum dots (CQDs) prepared in water and organic media were studied. The possibility to control luminescence peak position through technological parameters variation during synthesis process was shown and different luminescence mechanisms in CQDs were demonstrated. Cadmium selenide CQDs with inorganic shell of cadmium sulfide were synthesized and it allowed raising emission intensity several times.
\end{abstract}

Исследовались образцы коллоидных квантовых точек (CQDs) селенида кадмия, синтезированных в водной и органической средах. Показана возможность управления положением пика люминесценции за счет изменения технологических параметров в процессе синтеза, а также продемонстрированы различные механизмы люминесценции в CQDs. Синтезированы CQDs на основе селенида кадмия, покрытого неорганической оболочкой сульфида кадмия, что позволило повысить интенсивность люминесценции в несколько раз.

Дослідження люмінесцентних властивостей колоїдних квантових точок на основі халькогенідів кадмію. I.І.Михайлов, С.А.Тарасов, А.В.Соломонов, Л.Б.Матюшкін, Д.С.Мазінг.

Досліджено зразки колоїдних квантових точок (CQDs) селеніду кадмію, синтезованих у водному і органічному середовищах. Показано можливість керування положенням піка люмінесценції за рахунок зміни технологічних параметрів у процесі синтезу, а також продемонстровано різні механізми люмінесценції в CQDs. Синтезовано CQDs на основі селеніду кадмію, покриті неорганічною оболонкою сульфіду кадмію, що дозволило підвищити інтенсивність люмінесценції у декілька разів.

\section{Introduction}

For the last decade colloidal quantum dots (CQDs) have become an object of particularly intensive studying. CQDs are semiconductor particles of nanometer scale synthesized in liquid media and characterized by unique properties which substantially differ from bulk material properties. The most important feature of semiconductor nanoparticles is that they exhibit quantum size effects. These effects manifest them- selves in the discretization of the energy spectra and in dependence of the position of the energy levels from the geometric size of colloidal semiconductor nanoparticles. One of the most important advantages of CQDs is facility of geometric size tunability through technological parameters variation (time, temperature etc.) and that synthesis procedures don't require expensive equipment and materials. Therefore on the basis of the semiconductor nanoparticles both inexpensive analogs of modern nano- and op- 
toelectronics devices and principally new types of equipment can be developed. CQDs is promising material for a high-performance LED and laser structures creation, as well as photosensitizers in solar cells or luminophores in micro-devices for optical tomography of biological tissues.

\section{Experimental}

In order to investigate properties and characteristics of CQDs, methods of non-invasive optical spectroscopy were applied. These techniques are based on the utilizing of photoluminescence effects and allow obtaining information regarding particle size, crystal structure quality, quantum yield and other CQDs parameters [1].

A measuring device based on a quick scan spectrometer (QSS) Ocean Optics USB4000 allowing photoluminescence full range registration in a short time period was adjusted and configured to study photoluminescence spectra [2]. The sample in a quartz cell was placed into special holder and was excited by a focused laser radiation at a wavelength of $445 \mathrm{~nm}$. The photoluminescence signal was collected by the collimating optical system and was directed to the input QSS by means of a fiber. Data from the spectrometer was analyzed automatically by means of specialized software designed in the LabView environment [3].

In the first part of the work CdSe CQDs were prepared in aqueous medium with the use of thioglycolic acid (TGA) acting as surfactant. The particles were obtained by means of injection of NaHSe solution into cadmium containing precursor solution at approximately $97^{\circ} \mathrm{C}$. Synthesis lasted for $90 \mathrm{~min}$ and initial temperature was maintained constant. Molar ratio of the components amounted to $[\mathrm{TGA}]:[\mathrm{Cd}]:[\mathrm{Se}]=$ $1.4: 1: 0.6$. Samples were collected sequentially in the process of the reaction at definite points of time. Absorption and photoluminescence spectra of these nanoparticles are depicted in the Fig. 1. Absorption onset and photoluminescence peak shift to long-wavelength region with time which indicates that average nanoparticle size increases in the process of the reaction. It is noticeable that CQDs growth slows down after 25 min after injection. First excitonic peak becomes more pronounced for last samples indicating that nanoparticle size distribution somewhat narrows during the reaction [4]. This might be seen on photoluminescence spectra too where full width at half maximum (FWHM) parameter de-

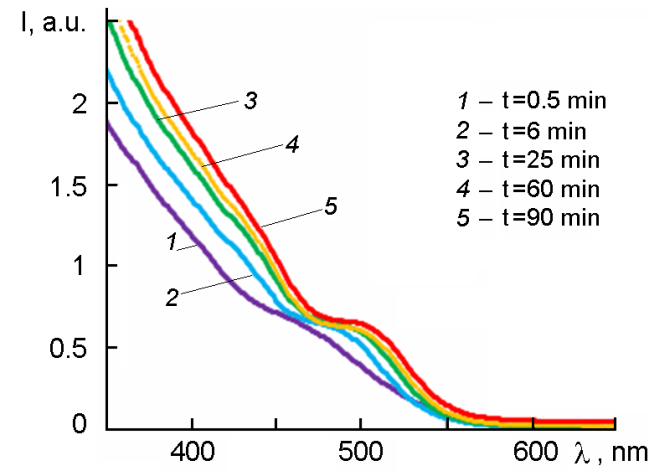

a)

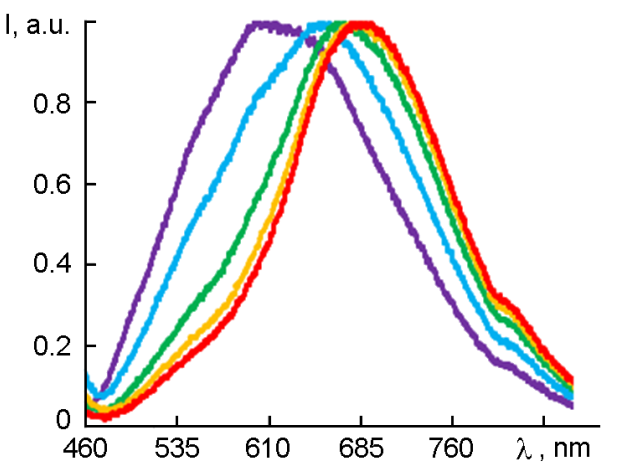

b)

Fig. 1. Normalized absorption spectra (a) and photoluminescence spectra (b) of CQDs synthesized in aqueous medium and stabilized with TGA: (1) 0,5 min, (2) $6 \mathrm{~min}$, (3) $25 \mathrm{~min}$, (4) $60 \mathrm{~min},(5) 90 \mathrm{~min}$ after injection.

creases from $200 \mathrm{~nm}$ for the first sample to $150 \mathrm{~nm}$ for the last one. At the same time large Stokes shift (wavelength discrepancy between first absorption transition and emission band) points to luminescence occurring through emissive recombination via defect states on the nanoparticle surface.

Further experiment was held where CdSe cores were coated with the shell of wider bandgap material CdS. Photoluminescence spectra of prepared samples are illustrated in the Fig. 2.

Sample 0 contains initial CdSe cores synthesized in water medium, obtained by the method similar to that described above. Sample 1 was prepared by following procedure. Initial solution of CdSe CQDs cores and Cd-TGA solution were mixed in the flask. Quantity of cadmium in Cd-TGA solution was 2.5 higher than in CdSe cores. Then $\mathrm{Na}_{2} \mathrm{~S}$ solution was added dropwise during $25 \mathrm{~min}$ so that resulting molar ratio was $[\mathrm{Cd}] /[\mathrm{S}]=1: 1$. Photoluminescence spectrum shifted towards short-wavelength region which may be attributed to forming of alloyed phase. Sample 2 was obtained by dropwise addition of $\mathrm{Na}_{2} \mathrm{~S}$ solution during $2.5 \min ([\mathrm{Cd}]:[S]=10: 1)$. Photolumines- 


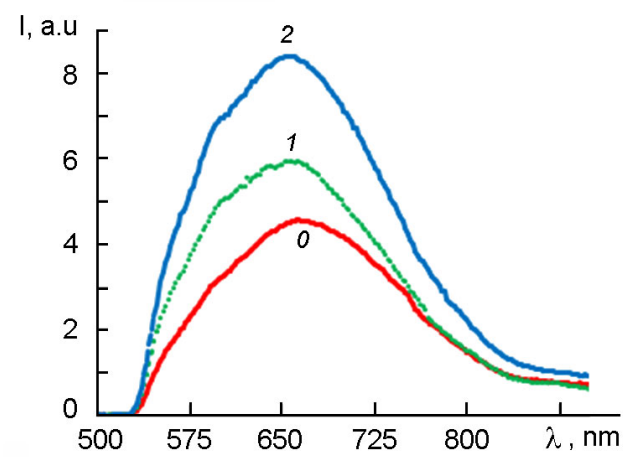

Fig. 2. Photoluminescence spectra of CdSe cores synthesized in aqueous medium without $(0)$ and with CdS shell $(1,2)$.

cence intensity for this sample increased twofold compared to uncoated nanoparticles, indicating that CdS shell provides surface defects passivation, hindering non- radiative recombination and thus increasing quantum yield.

The synthesis of colloidal CdSe quantum dots in organic medium was carried out in the second part of the work. Cadmium precursor solution was prepared by mixing $\mathrm{CdO}$, oleic acid and liquid paraffin followed by heating to $150^{\circ} \mathrm{C}$. Selenium precursor was obtained through heating selenium powder and liquid paraffin mixture to $220^{\circ} \mathrm{C}$. The introduction of cadmium containing solution into selenium precursor solution was carried out at the temperature of $240^{\circ} \mathrm{C}$. Samples were obtained at intervals of 1,2 and 5 min. Fig. 3 shows absorption and photoluminescence spectra of the synthesized CQDs.

The spectra reveal two radiation regions: a high intensity peak on the left side of the characteristics and a broad plateau of a lower intensity on the right. We consider luminescence peak on the left that shifts from $470 \mathrm{~nm}$ to $520 \mathrm{~nm}$ wavelength with synthesis time to correspond to intraband transition. It is caused by the CQDs growth during the CQDs synthesis that leads to a decrease of the band gap so that the emission shifts to a longwave region. The FWHM of the peak was approximately $50 \mathrm{~nm}$ and decreased slightly in the course of the reaction which reflects relatively high monodispersity. The occurrence of plateau in the longwave region of the graph can be explained by existence of the QD surface defects that act as trap levels within band gap and provide the route for concurrent radiative recombination. With time oleic acid molecules passivate these surface states more efficiently and as a re-

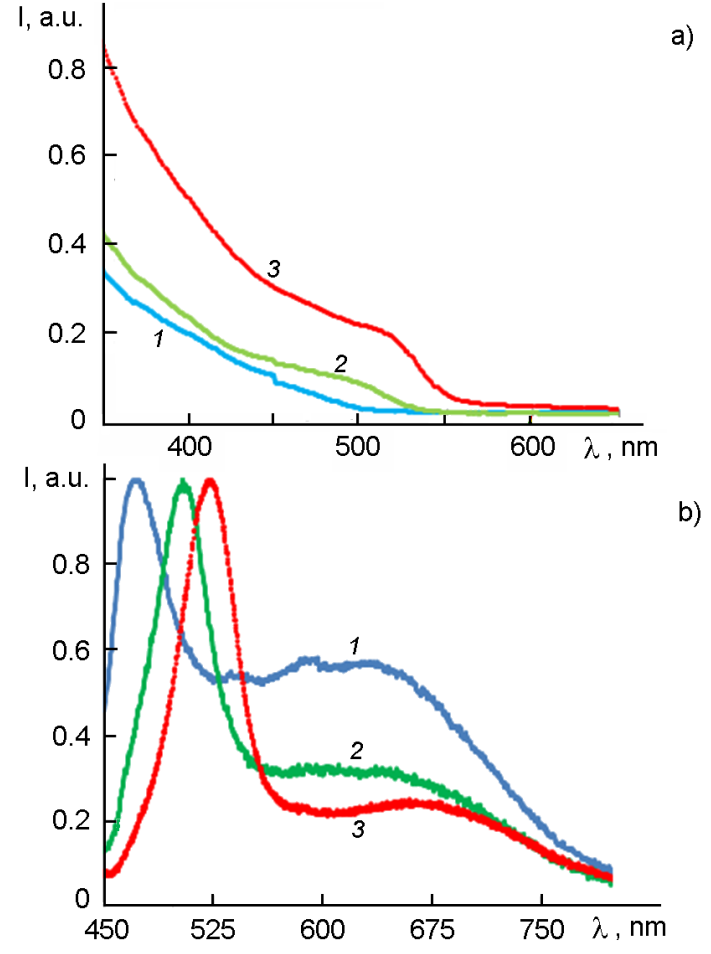

Fig. 3. Normalized absorption (a) and photoluminescence spectra (b) of CdSe quantum synthesized in organic medium: (1) $1 \mathrm{~min},(2)$ 2 min, (3) 5 min after injection.

sult the photoluminescence intensity caused by defects decreases in comparison with intraband emission.

\section{Conclusions}

Cadmium selenide CQDs were prepared in organic and aqueous solutions, their properties and characteristics were investigated by means of optical spectroscopy. Photoluminescence intensity for nanoparticles synthesized in organic medium is much higher than those prepared in water. It may be explained by higher reaction temperatures in the first case that facilitate formation of nanocrystals with better crystallinity. Moreover samples that are obtained in organics are characterized by more narrow size distribution.

Quality of crystal structure and state of nanoparticle surface affect photoluminescence immensely. Coating of CdSe CQDs with wide band gap CdS resulted in surface defects passivation and increasing of emission intensity twofold.

Synthesized nanoparticles are planned to be used as luminophores [5] for $\mathrm{mi}$ crodevices of optical tomography of biological tissues. Work on white light-emitting 
devices with high CRI based on nitride structures and CQDs is carried out as well [6]. We actively develop tunable lasers in a wide range of wavelengths. We design a new type of solar cell with a selective absorption with using of different photodetectors in their construction, including solarblind detectors [7].

\section{References}

1. I.I.Mikhailov, S.A.Tarasov, A.V.Presnyakova, D.S.Romanovsky, Izvestiya ETU "LETI", 5, 22 (2013).
2. S.A.Tarasov, I.E.Gracheva, K.G.Gareev et al., Semiconductors, 46, 1584 (2012).

3. E.A.Menkovich, S.A.Tarasov, I.A.Lamkin, Functional Materials, 19, 233 (2012).

4. S.A.Tarasov, O.A.Alexandrova, A.I.Maksomiv et al., Higher Education Institute Electronics, 3, 28 (2013).

5. O.A.Alexandrova, A.I.Maximov, E.V.Maraeva et al., Nano- and Microsyst. Techn., 2, 19 (2013).

6. E.A.Menkovich, S.A.Tarasov. I.A.Lamkin et al., J..Phys.:Conf.Ser., 461, 012028 (2013).

7. I.Lamkin, S.Tarasov, J..Phys.:Conf.Ser., 461, 012025 (2013). 